\title{
PENGARUH PROFITABILITAS, RISIKO BISNIS DAN TINGKAT SUKU BUNGA TERHADAP STRUKTUR MODAL (Perusahaan Transportasi Periode 2012-2015)
}

\author{
Ira Puspita ${ }^{1}$ \\ Sayu Ketut Sutrisna Dewi ${ }^{2}$ \\ ${ }^{1,2}$ Fakultas Ekonomi dan Bisnis Universitas Udayana, Bali, Indonesia \\ Email: puspitaira6@gmail.com
}

\begin{abstract}
ABSTRAK
Struktur modal merupakan bagian dari struktur keuangan yang menjaga perimbangan antara total hutang dengan modal sendiri. Tinggi rendahnya struktur modal akan mencerminkan bagaimana posisi keuangan perusahaan tersebut. Keputusan struktur modal adalah salah satu kunci keputusan keuangan dalam membiayai aktiva dan meningkatkan modal bisnis. Penelitian ini bertujuan untuk mengetahui bagaimana pengaruh profitabilitas, risiko bisnis dan tingkat suku bunga terhadap struktur modal. Sampel dalam penelitian ini adalah perusahaan transportasi mulai dari tahun 2012-2015 yang berjumlah 24 perusahaan, dengan teknik pengambilan sampel menggunakan purposive sampling. Berdasarkan metode analisis regresi linier berganda, penelitian ini menemukan bahwa profitabilitas berpengaruh positif signifikan terhadap struktur modal, risiko bisnis dan tingkat suku bunga berpengaruh negatif signifikan terhadap struktur modal.
\end{abstract}

Kata kunci: Struktur modal, profitabilitas, risiko bisnis, tingkat suku bunga.

\begin{abstract}
Capital structure is part of the financial structure that keeps the balance between total debt with own capital. The high capital structure will reflect how the company's financial position. Capital structure decisions are one of the key financial decisions in financing assets and increasing business capital. This study aims to find out how the influence of profitability, business risk and interest rates on capital structure. The sample in this research is transportation company starting from 2012-2015 which amounts to 24 companies, with sampling technique using purposive sampling. Based on multiple linier regression analysis method, this research found that profitability have significant positive effect to capital structure, business risk and interest rate have significant negative effect to capital structure.
\end{abstract}

Keywords: Capital structure, profitability, business risk, interest rate. 


\section{PENDAHULUAN}

Modal merupakan bagian yang penting dalam mendukung aktivitas yang terjadi di dalam perusahaaan. Perusahaan dalam menjalankan kegiatan operasionalnya selalu menghadapi masalah dari mana dana berasal dan untuk apa dana tersebut dimanfaatkan. Secara umum sumber pendanaan di bagi menjadi dua bentuk yaitu pendanaan eksternal berupa dana pinjaman dari supplier, bank dan pasar modal serta pendanaan internal yang berupa laba ditahan (Wiagustini, 2014:234). Menurut Setiawati, (2011) dalam menentukan struktur modal perusahaan perlu mengusahakan tercapainya keseimbangan yang optimal dari penggunaan sumber dana tersebut. Struktur modal menjadi suatu masalah yang sangat penting karena posisi keuangan suatu perusahaan akan dilihat dari tinggi rendahnya struktur modal suatu perusahaan. Manajer diharapkan mampu menghimpun dana baik yang bersumber dari internal perusahaan maupun dari eksternal perusahaan secara efisien, dalam arti keputusan yang diambil manajer tersebut diharapkan dapat meminimalkan biaya modal yang akan ditanggung perusahaan.

Weston dan Copeland 2002 (dalam Wahyuni 2013) menyatakan tujuan struktur modal adalah untuk mencapai bauran yang terbaik antara utang jangka panjang dan ekuitas yang akan mengoptimalkan keseimbangan antara pengembalian dan risiko sehinggaakan memaksimumkan harga saham.

Perusahaan dalam aktivitasnya tidak terlepas dari interaksi dengan berbagai elemen masyarakat sekelilingnya karena berkaitan dengan perilaku ekonomi 
seperti distributor, stake holder, produsen pesaing dan investor baik individu maupun badan usaha, konsumen, serta pemerintah yang membuat kebijakan dan peraturan sebagai perannya dalam mengontrol pertumbuhan ekonomi. Setiap hubungan yang terjadi dalam aktivitas perusahaan dan elemen lainnya tentu saja akan berdampak pada keputusan pendanaan yang diambil perusahaan. Salah satunya adalah inflasi. Inflasi adalah suatu keadaan perekonomian dimana hargaharga secara umum mengalami kenaikan dalam waktu yang panjang. Tingginya inflasi pada umumnya diiringi dengan naiknya tingkat bunga untuk mengurangi penawaran uang berlebih (Mankiw, 2013:167-168).

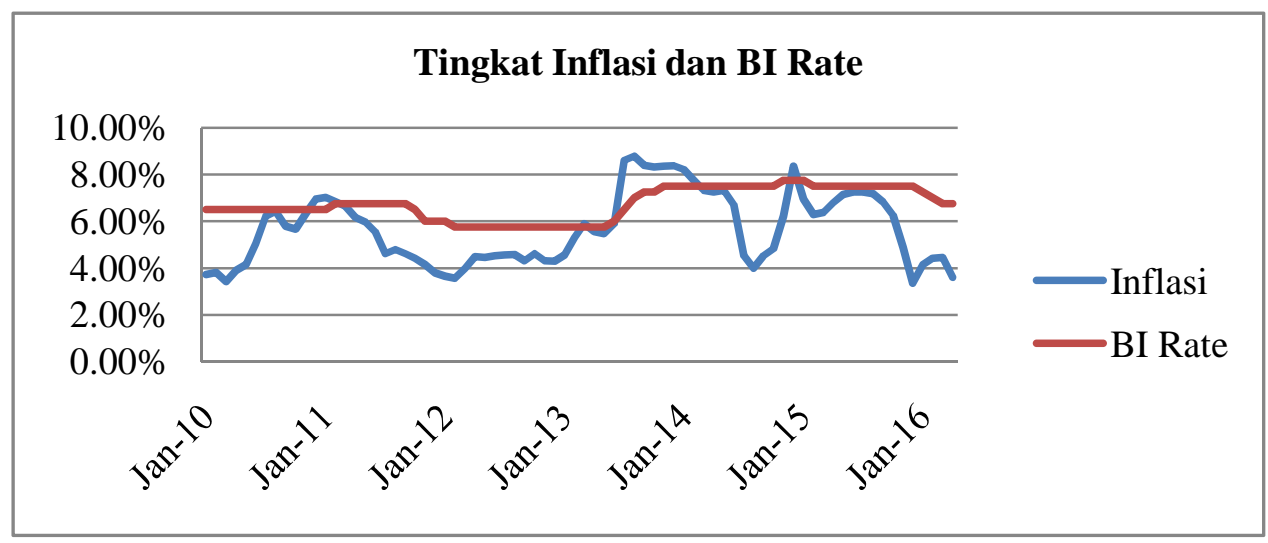

Gambar 1.Tingkat Inflasi dan BI Rate Per Januari 2010-Januari 2016 Sumber:www.bi.go.id, 2017

Semakin tinggi tingkat suku bunga maka keputusan pendanaan dengan utang akan berisiko besar bagi perusahaan, karena menimbulkan biaya bunga yang besar dan kemungkinan perusahaan tidak dapat melunasi kewajibannya menjadi lebih tinggi. Indrajaya dkk. (2011) menjelaskan, naiknya BI Rate ini juga menyebabkan mengingkatnya tingkat bunga pinjaman, yang pada akhirnya akan menyebabkan sektor riil terkena dampaknya sehingga dapat menyebabkan 
peningkatan biaya produksi akibat tingginya biaya produksi dan beban bunga kredit. Naiknya biaya produksi dan beban bunga serta melemahnya daya beli masyarakat akan meningkatkan risiko perusahaan terhadap ancaman kebangkrutan.

Debt to Total Asset Ratio merupakan rasio utang yang digunakan untuk mengukur perbandingan antara total utang dengan total aktiva, atau seberapa aktiva perusahaan di biayai oleh utang atau seberapa besar utang perusahaan berpengaruh terhadap pengelolaan aktiva. Semakin tinggi nilai DAR berarti semakin besar sumber dana melalui pinjaman untuk membiayai aktiva. Nilai DAR yang tinggi menunjukan risiko yang tinggi pula karena ada kekhawatiran perusahaan tidak mampu menutupi hutang-hutangnya dengan aktiva yang dimilikinya sehingga untuk mendapatkan tambahan pinjaman akan semakin sulit (Kasmir, $2014: 156)$.

Menurut Sudana (2011:22) Profitabilitas menunjukan kemampuan perusahaan untuk menghasilkan laba dengan menggunakan sumber-sumber yang dimiliki perusahaan. Tingkat pengembalian yang tinggi akan memungkinkan untuk membiayai sebagian besar kebutuhan pendanaan dengan dana yang dihasilkan oleh internal perusahaan (Mardiansyah, 2013).

Risiko bisnis merupakan risiko yang timbul akibat ketidak pastian perusahaan dalam menghasilkan pendapatan dimasa yang akan datang. Perusahaan harus memenuhi segala kewajiban yang timbul akibat pinjaman yang diperoleh perusahaan. Perusahaan dengan jumlah hutang yang tinggi dapat memicu timbulnya risiko bisnis karena perusahaan harus mampu memenuhi 
kewajibannya serta beban bunga yang ditanggung oleh perusahaan. Perusahaan yang labanya berfluktuasi dapat dikatakan bahwa perusahaan tersebut sedang menghadapi risiko bisnis (Amiriyah, 2014).

Tingkat suku bunga merupakan rasio pengembalian sejumlah investasi sebagai bentuk imbalan yang diberikan kepada investor. Jika pertumbuhan ekonomi lambat dan laba perusahaan menurun perusahaan hendaknya mengurangi hutangnya karena menutup pembayaran bunga jauh lebih sulit untuk dilakukan, jika suku bunga turun perusahaan dapat menambah utangnya karena pembayaran bunga yang relatif rendah.

\section{Tabel1.}

Nilai Rata-Rata DAR, ROA, Brisk dan BI Rate pada Perusahaan Transportasi Periode 2012-1015

\begin{tabular}{lrrrr}
\hline Proxi/Tahun & \multicolumn{2}{c}{$\mathbf{2 0 1 2}$} & $\mathbf{2 0 1 3}$ & \multicolumn{2}{c}{$\mathbf{2 0 1 4}$} & \multicolumn{1}{c}{$\mathbf{2 0 1 5}$} \\
\hline DAR (\%) & 83 & 81 & 79 & 49 \\
ROA (\%) & 1,69 & 0,11 & 10,27 & 13,83 \\
BRISK (\%) & 10,88 & 22,39 & 13,48 & 13,46 \\
BI RATE (\%) & 5,77 & 6,48 & 7,54 & 7,52 \\
\hline
\end{tabular}

Sumber:www.bei.co.id, 2017

Berdasarkan Tabel 1 menggambarkan bahwa menurunnya nilai ROA sepanjang tahun 2012 hingga 2013 juga diikuti dengan penurunan nilai DAR dari tahun 2012 hingga 2013, namun peningkatan nilai ROA dari tahun 2013 hingga 2015 tidak diikuti pula dengan peningkatan nilai DAR di tahun yang sama. Brisk di tahun 2012 sebesar 10,88 persen dan mengalami peningkatan di tahun 2013 mencapai nilai 22,39 persen, diikuti dengan penurunan nilai DAR di tahun yang sama, namun menurunnya nilai brisk di tahun 2014 tidak diikuti dengan meningkatnya nilai DAR di tahun 2014, sedangkan BI Rate di tahun 2012 hingga 
2014 mengalami kenaikan dan mengalami penurunan sebesar 0,02 persen di tahun 2015 namun penurunan nilai ini BI Rate tidak diikuti dengan meningkatnya nilai DAR.

Dewanti (2011) pertumbuhan perekonomian suatu negara sulit mencapai hasil yang optimum tanpa adanya sarana penunjang salah satunya adalah transportasi. Pentingnya transportasi di negara Indonesia disebabkan oleh beberapa faktor lain, keadaan geografis Indonesia yang terdiri dari ribuan pulau kecil dan besar, perairan yang terdiri dari sebagian besar laut, sungai dan danau yang memungkinkan pengangkutan dilakukan melalui darat, perairan, udara guna menjangkau seluruh wilayah Indonesia. Ketersediaan prasarana dan sarana yang mencukupi dan efektif, serta tumbuhnya industri jasa yang efisien dan berdaya saing tinggi pada setiap perhubungan, baik darat, laut maupun udara, akan menentukan kecepatan pertumbuhan perekonomian Indonesia mengatasi persaingan global yang semakin ketat dan berat. Peran perusahaan transportasi sangatlah besar khususnya bagi negara-negara berkembang yang harus mempererat hubungan negaranya dengan negara-negara maju maupun negaranegara berkambang lainnya, seperti halnya kegiatan ekspor dan impor.

Penelitian Zhang (2010) menemukan profitabilitas berpengaruh positif terhadap struktur modal. Hasil berbeda ditemukan pada penelitian Liu dan Xiangbao (2009) yang menemukan bahwa profitabilitas berpengaruh negatif dan signifikan terhadap struktur modal. Mufidah (2012) dalam penelitian dengan judul struktur modal perusahaan property dan faktor-faktor yang mempengaruhinya memberikan hasil bahwa tingkat suku bunga berpengaruh negatif dan tidak 
signifikan terhadap struktur modal. Sementara Ilhamy (2013) menunjukan tingkat suku bunga berpengaruh negatif dan signifikan terhadap struktur modal. Susetyo (2006) dalam penelitiannya membuktikan bahwa risiko bisnis berpengaruh negatif dan signifikan terhadap struktur modal perusahaan. Indrajaya dkk. (2012) menyatakan risiko bisnis berpengaruh positif tidak signifikan terhadap struktur modal.

Berdasarkan latar belakang yang telah diuraikan sebelumnya, maka rumusan masalah penelitian ini (1) Apakah profitabilitas berpengaruh signifikan terhadap struktur modal perusahaan transportasi periode 2012-2015? (2) Apakah risiko bisnis berpengaruh signifikan terhadap struktur modal perusahaan transportasi periode 2012-2015? (3) Apakah tingkat suku bunga berpengaruh signifikan terhadap struktur modal perusahaan transportasi periode 2012-2015? Berdasarkan dari permasalahan yang telah diuraikan, maka tujuan dari penelitian ini (1) Untuk mengetahui signifikansi pengaruh profitabilitas terhadap struktur modal perusahaan transportasi periode 2012-2015 (2) Untuk mengetahui signifikansi pengaruh risiko bisnis terhadap struktur modal perusahaan transportasi periode 2012-2015 (3) Untuk mengetahui signifikansi pengaruh tingkat suku bunga terhadap struktur modal perusahaan transportasi periode 2012-2015. Berdasarkan latar belakang, perumusan masalah, dan tujuan yang telah diuraikan sebelumnya, maka kegunaan penelitian ini (1) Kegunaan Teoritis: Penelitian ini diharapkandapat digunakan sebagai salah satu hasil studi empiris untuk memberikan pemahaman dalam mengembangkan dan mengaplikasikan teori-teori mengenai pengaruh profitabilitas, tingkat suku bunga dan risiko bisnis yang 
berpengaruh terhadap struktur modal. (2) Kegunaan Praktis: Penelitian ini diharapkan dapat membantu investor sebagi bentuk pertimbangan untuk mengambil keputusan investasi dengan melihat struktur modal perusahaan tersebut.

Landasan teori pada penelitian ini yang pertama adalah Pecking Order Theory:Teori pecking order adalah teori yang menjelaskan bahwa manajemen secara sistematis mendahulukan pendanaan investasi dengan menggunakan dana internal (laba ditahan) daripada penggunaan dana eksternal dan mendahulukan utang dari pada ekuitas jika pendanaan eksternal dibutuhkan (Gunawan, 2011). Myers dan Majluf pada tahun 1984 mengemukakanpecking order theory. Teori ini mengemukakan perusahaan akan lebih cenderung untuk menggunakan sumber pendanaan internal yaitu dari laba ditahan dan depresiasi terlebih dahulu, dari pada menggunakan dana yang bersumber dari eksternal perusahaan. Perusahaan akan menggunakan dana eksternal pada saat perusahaan tidak memiliki dana internal yang memadai, jika dana eksternal dipilih maka perusahaan akan cenderung menggunakan hutang dari pada ekuitasnya. Menurut Al-Shubiri (2010) untuk mendanai sebuah proyek manajer pertama kali akan menggunakan laba ditahan.

Landasan teori kedua Trade off Theory:Trade off theory (teori pertukaran) adalah teori struktur modal yang menyatakan bahwa perusahaan menukarkan manfaat pajak dari penggunaan utang dengan masalah yang ditimbulkan oleh potensi kebangkrutan (Brigham dan Houston, 2011:183). Menurut Hartono, (2003) trade off mengansumsikan bahwa struktur modal perusahaan merupakan 
hasil trade off dari keuntungan pajak dengan menggunakan utang dengan biaya yang akan timbul sebagai akibat penggunaan utang tersebut.Sartono (2010:247) menyatakan bahwa trade off theory merupakan perbandingan antara kerugian dan keuntungan dari penggunaan utang. Teori ini memperkitakan bahwa setiap perusahaan akan memperhitungkan jumlah utang yang optimal, yang akan menyeimbangkan keuntungan perlindungan pajak dengan beban sebagai akibat penggunaan utang yang semakin besar. Menurut Insiroh (2014) esensi trade off theory dalam struktur modal adalah penyeimbang manfaat dan pengorbanan yang timbul sebagai akibat penggunaan hutang.

Landasan teori ketiga Agency Theory:Agency teory menyarankan bahwa optimal capital dan ownership structures bisa digunakan untuk mengurangi biaya agensi. Biaya agensi atau biaya keagenan adalah biaya yang timbul karena perusahaan menggunakan utang dan melibatkan hubungan antara pemilik perusahaan (pemegang saham) dan kreditor. Biaya keagenan ini muncul dari problem keagenan agency problematau. Jika perusahaan menggunakan utang ada kemungkinan pemilik perusahaan melakukan tindakan yang merugikan kreditor. Jensen dan Meckling (1976) mengemukakan bahwa agency theory adalah pemisahan kepemilikan dan kekuasaan didalam mengendalikan perusahaan, yang dapat menciptakan konflik kepentingan antara pemegang saham perusahaan dengan manajer. Problem keagenan (agency problem) antara pemegang saham dengan manajer potensial terjadi bila manajemen tidak memiliki saham mayoritas perusahaan. Pemegang saham menginginkan manajer bekerja dengan tujuan memaksimumkan kemakmuran pemegang saham. Sebaliknya, manajer 
perusahaan bisa saja bertindak tidak untuk memaksimumkan kemakmuran pemegang saham, tetapi memaksimumkan kemakmuran dirinya sendiri. Untuk meyakinkan bahwa manajer bersungguh-sungguh untuk kepentingan pemegang saham, pemegang saham harus mengeluarkan biaya yang disebut agency cost.

Landasan teori keempat Teori Signaling:Sinyal adalah sebuah tindakan yang dilakukan oleh manajemen perusahaan yang memberi petunjuk bagi pemegang saham tentang bagaimana manajemen mendatang prospek perusahaan. Perusahaan dengan prospek yang menguntungkan akan mencoba menghindari penjualan saham dan ngusahakan setiap modal baru yang diperlukan dengan cara-cara lain, termasuk penggunaan utang yang melebihi target struktur modal yang normal. Deesomsak et al. (2004) serta Alves dan Fereira (2011) mendukung adanya pengaruh prospek perusahaan terhadap struktur modal. Menurut Brigham dan Houston (2011:186) isyarat atau signal adalah suatu tindakan yang diambil manajemen perusahaan yang akan memberi petunjuk bagi investor tentang bagaimana manajemen memandang prospek perusahaan.

Perusahaan dengan prospek yang terlihat kurang menguntungkan akan memilih untuk menjual sahamnya. Pengumuman emisi saham oleh suatu perusahaan pada umumnya merupakan suatu signal bahwa manajemen memandang prospek peusahaan tersebut suram. Namun, perusahaan akan terlihat positif dimata investor ketika perusahaan tersebut mendapat pinjaman dari kreditur. Jadi teori ini lebih memilih untuk menggunakan dana eksternal untuk pendanaan perusahaannya yang akan memberikan sinyal positif bagi para investor untuk menanamkan modalnya. 
Perusahaan yang memiliki tingkat keuntungan yang tinggi akan menggunakan utang relatif kecil. Tingkat keuntungan yang tinggi memungkinkan perusahaan untuk memperoleh sebagian pendanaanya dari modal sendiri yaitu laba ditahan. Brigham dan Houston (2011:40) menyatakan bahwa perusahaan dengan tingkat pengembalian yang tinggi atas investasi akan menggunakan utang yang relatif kecil. Perusahaan dengan tingkat pengembalian yang tinggi memungkinkan perusahaan untuk membiayai sebagian besar kebutuhan pendanaannya dengan dana internal. Menurut Harris dan Raviv (1991) semakin tinggi profit suatu perusahaan maka hutangnya akan semakin rendah. Hal ini juga sejalan dengan teori pecking order, dimana teori pecking order mengatakan bahwa perusahaaan yang mampu membiayai pendanaannya menggunakan sumber internal cenderung tidak akan mencari dana dari pihak eksternal.

Para investor menanamkan saham pada perusahaan juga memandang perusahaan memiliki prospek kedepan yang cerah, dengan begitu investor akan tertarik untuk menanamkan modalnya. Investor menginginkan kembalian atas penanaman sahamnya berupa return yang terdiri dari yield dan capital gain, semakin tinggi kemampuan memperoleh laba, maka semakin besar investor yang berminat menanamkan modalnya dan semakin besar return yang diharapkan investor tersebut. Berdasarkan penjelasan tersebut dapat disimpulkan bahwa tingkat profitabilitas yang semakin tinggi akan mempermudah perusahaan untuk mendapatkan dana asing berupa hutang untuk membiayai aktivitas perusahaannya.

Penelitian yang dilakukan oleh Hermuningsih (2012) dan Gunawan (2011) mendapatkan hasil bahwa profitabilitas memiliki pengaruh positif signifikan 
terhadap struktur modal. Berdasarkan teori dan penelitian terdahulu tersebut, maka hipotesis pertama pada penelitian ini adalah sebagai berikut:

$\mathrm{H}_{1}$ : Profitabilitas berpengaruh positif dan signifikan terhadap struktur modal.

Menurut Brigham dan Houston (2011:157) risiko usaha akan menunjukan seberapa besar risiko perusahaan jika suatu perusahaan tidak menggunakan hutang. Semakin tinggi risiko bisnis, maka probabilitas terjadinya financial distress juga semakin tinggi. Susetyo (2006) dalam penelitiannya membuktikan bahwa risiko bisnis berpengaruh negatif dan signifikan terhadapstruktur modal perusahaan. Hal ini sesuai dengan teori trade off, dimana semakin tinggi kemungkinan financialdistress akan semakin tinggi pula kemungkinanan financial distress costs yang harus di tangung perusahaan, ini akan menyebabkan tingkat penggunaan utang yang optimum semakin rendah, sehingga perusahaan seharusnya menggunakan lebih sedikit utang. Berdasarkan teori dan hasil penelitian terdahulu maka dapat dirumuskan hipotesis penelitian yang kedua sebagai berikut:

$\mathrm{H}_{2}$ : Risiko bisnis berpengaruh negatif dan signifikan terhadap struktur modal.

Tingkat suku bunga merupakan rasio pengembalian sejumlah investasi sebagi bentuk imbalan yang diberikan kepada investor. Jika pertumbuhan ekonomi lambat dan laba perusahaan menurun perusahaan hendaknya mengurangi utangnya karena menutup pembayaran bunga jauh lebih sulit untuk dilakukan, jika suku bunga turun perusahaan dapat menambah utangnya karena pembayaran bunga yang relatif rendah. Ilhamy (2013) dalam penelitiannya menunjukan tingkat suku bunga berpengaruh negatif dan signifikan terhadap struktur modal. 
Berdasarkan pemaparan dan penelitian terdahulu maka hipotesis kedua pada penelitian ini adalah:

$\mathrm{H}_{3}$ : Tingkat suku bunga berpengaruh negatif dan signifikan terhadap struktur modal.

\section{METODE PENELITIAN}

Desain dalam penelitian ini menggunakan desain dengan pendekatan kuantitatif yang berbentuk asosiatif kausal. Penelitian ini bertujuan untukmengetahui pengaruh profitabilitas, risiko bisnis dan tingkat suku bunga terhadap struktur modal. Penelitian ini dilakukan pada perusahaan transportasi yang terdaftar di Bursa Efek Indonesia dengan cara pengambilan data pada laporan keuangan tahunan perusahaan transportasi periode 2012-2015. Obyek yang digunakan dalam penelitian ini adalah struktur modal pada perusahaan transportasi di Bursa Efek Indonesia periode 2012-2015.

Variabel terikat (dependent) dalam penelitian ini adalah struktur modal. Struktur modal dalam penelitian ini dihitung dengan debt to total assets ratio (DAR) yaitu perbandingan antara total utang dengan total aktiva dari tahun 20122015 pada perusahaan trasportasi di Bursa Efek Indonesia. Satuan debt tototal assets ratio adalah persentase. Wiagustini (2014:88) Debt to Total Assets Ratio dapat dihitung dengan rumus sebagai berikut:

$\operatorname{DAR}=\frac{\mathrm{T} \quad \mathrm{U}}{\mathrm{I} \mathrm{L}} \mathrm{A} \quad \mathrm{X} 100 \%$

Variabel bebas (independent) yang digunakan dalam penelitian ini adalah profitabilitas, risiko bisnis dan tingkat suku bunga. Profitabilitas merupakan kemampuan suatu perusahaan untuk menghasilkan laba. Tingkat profitabilitas 
memperlihatkan kemampuan perusahaan untuk mendapatkan keuntungan perusahaan dalam periode tertentu yang disajikan dalam persentase. Profitabilitas dalam penelitaian ini diproduksi dengan Return on Asset (ROA). ROA merupakan rasio yang menggambarkan perputaran aktiva yang diukur dari volume penjualan.Menurut Wiagustini (2014:90) rasio ini dapat dihitung dengan rumus sebagai berikut.

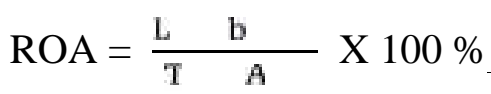

Risiko bisnis merupakan risiko dalam menjalankan suatu jenis bisnis (Tandelilin, 2010:104). Menurut Brigham dan Houston (2011:157) risiko usaha akan menunjukan seberapa besar risiko perusahaan jika suatu perusahaan tidak menggunakan hutang. Menurut Weston dan Thomas E. Copeland (1989) proksi risiko bisnis diukur dengan standar devisiasi hasil pengembalian yang diharapkan sebelum pajak (EBIT) terhadap aset perusahaan dalam bentuk persentase dengan rumus sebagai berikut:

Risiko Bisnis $=\sigma \frac{\mathrm{E}}{\mathrm{T} \quad \mathrm{A}} \mathrm{X} 100 \%$

Suku bunga adalah harga yang dibebankan untuk meminjam uang Madura (2007: 447) bunga juga dapat di artikan sebagai balas jasa atas pinjaman yang di berikan. Tingkat suku bunga yang digunakan adalah BI Ratebulanan yang dipublikasikan oleh Bank Indonesia periode 2012-2015 yang disajikan dalam bentuk persentase.

Jenis data yang digunakan dalam penelitian ini adalah data kuantitatif dan sumber data yang digunakan adalah data sekunder yang diperoleh dari Bursa Efek Indonesia dan Bank Indonesia, berupa data struktur modal (DAR), profitabilitas (ROA), risiko bisnis ( $\sigma E B I T / T o t a l$ Aset) dan tingkat suku bunga Indonesia 
(BIRate). Populasi dalam penelitian ini adalah perusahaan transportasi yang terdaftar di Bursa Efek Indonesia sebanyak 35 perusahaan. Jumlah sampel yang digunakan dalam penelitian ini sebanyak 24 perusahaan. Teknik penentuan sampel dalam penelitian ini menggunakanmetode purposive sampling. Adapun kriteria yang digunakan dalam pengambilan sampel adalah perusahaantransportasi yang terdaftar di Bursa Efek Indonesia periode 2012-2015. Pengumpulan data dalam penelitian ini dilakukan dengan cara non participant observation. Teknik analisis data yang digunakan dalam penelitian ini adalah analisis regresi linier berganda.

\section{HASIL DAN PEMBAHASAN}

Statistik deskriptif disajikan untuk memberikan informasi mengenai nilai minimum, maksimum, rata-rata (mean) dan nilai standar deviasi dari variabel penelitian.

Tabel 2.

Statistik Deskriptif

\begin{tabular}{lrrrrr}
\hline & N & Minimum & Maximum & \multicolumn{1}{c}{ Mean } & $\begin{array}{c}\text { Std. } \\
\text { deviation }\end{array}$ \\
\hline Struktur Modal & 96 & 3,00 & 271,00 & 72,9530 & 51,99037 \\
Profitabilitas & 96 & $-37,46$ & 185,17 & 6,4721 & 27,75018 \\
Risiko Bisnis & 96 & 0,57 & 87,73 & 15,0522 & 18,99615 \\
Tingkat Suku Bunga & 96 & 5,77 & 7,54 & 6,8275 & 0,74995 \\
Valid N (listwise) & 96 & & & & \\
\hline Sumber:www.bei.co.id,2017 & & & & &
\end{tabular}

Berdasarkan hasil pengujian statistik deskriptif diperoleh nilai minimum variabel struktur modal sebesar 3. Nilai minimum tersebut dimiliki oleh perusahaan PT. ICTSI Jasa Prima Tbk. sedangkan nilai maksimum variabel 
struktur modal dimiliki oleh perusahaan PT. Tanah Laut Tbk. sebesar 271. Nilai rata-rata dari variabel struktur modal adalah sebesar 72,9530 atau 7295,30 persen. Standar deviasi dari variabel struktur modal adalah sebesar 51,99037 atau 5199,037 persen.

Berdasarkan hasil pengujian statistik deskriptif diperoleh nilai minimum variabel profitabilitas sebesar -37,46. Nilai minimum tersebut dimiliki oleh perusahaan PT. Mitra Bantera Segara Sejati Tbk. sedangkan nilai maksimum variabel profitabilitas dimiliki oleh perusahaan PT. Tanah Laut Tbk.sebesar 185,17. Nilai rata-rata dari variabel profitabilitas adalah sebesar 6,4721 atau 647,21 persen. Standar deviasi dari variabel profitabilitas adalah sebesar 27,75018 atau 2775,018 persen.

Berdasarkan hasil pengujian statistik deskriptif diperoleh nilai minimum variabel risiko bisnis sebesar 0,57 . Nilai minimum tersebut dimiliki oleh perusahaan PT. Mitra International Resources Tbk. sedangkan nilai maksimum variabel risiko bisnis dimiliki oleh perusahaan PT. Trada Maritime Tbk. sebesar 87,73. Nilai rata-rata dari variabel risiko bisnis adalah sebesar 15,0522 atau 1505,22 persen. Standar deviasi dari variabel risiko bisnis adalah sebesar 18,99615 atau 1899,615 persen.

Berdasarkan hasil pengujian statistik deskriptif diperoleh nilai minimum variabel tingkat suku bunga sebesar 5,77. Nilai minimum tersebut dimiliki oleh perusahaan PT. Arpeni Pratama Ocean Line Tbk. PT. Adi Sarana Armada Tbk. PT. Berlian Laju Tanker Tbk. PT. Buana Listya Tama Tbk. PT. Cardig Aero Services Tbk. PT. Garuda Indonesia (Persero) Tbk. PT. Humpuss Intermoda 
Transportasi Tbk. PT. Indonesia Air Transport Tbk. PT. Tanah Laut Tbk. PT. ICTSI Jasa Prima Tbk. PT. Mitra Bantera Segara Sejati Tbk.PT. Mitra International Resources Tbk. PT. Pelayaran Nelly Dwi Putri Tbk. PT. Indo Straits Tbk. PT. Rig Tenders Indonesia Tbk. PT. Steady Safe Tbk. PT. SidomulyoSelaras Tbk. PT. Samudera Indonesia Tbk. PT. Express Transindo Utama Tbk. PT. Pelayaran Tempur Emas Tbk. PT. Trada Maritime Tbk. PT. Weha Transportasi Indonesia Tbk. PT. Wintermar Offshore Marine Tbk. PT. Zebra Nusantara Tbk. sedangkan nilai maksimum variabel tingkat suku bunga dimiliki oleh perusahaan PT. Arpeni Pratama Ocean Line Tbk. PT. Adi Sarana Armada Tbk. PT. Berlian Laju Tanker Tbk. PT. Buana Listya Tama Tbk. PT. Cardig Aero Services Tbk. PT. Garuda Indonesia (Persero) Tbk. PT. Humpuss Intermoda Transportasi Tbk.PT. Indonesia Air Transport Tbk. PT. Tanah Laut Tbk. PT. ICTSI Jasa Prima Tbk. PT. Mitra Bantera Segara Sejati Tbk. PT. Mitra International Resources Tbk. PT. Pelayaran Nelly Dwi Putri Tbk. PT. Indo Straits Tbk. PT. Rig Tenders Indonesia Tbk. PT. Steady Safe Tbk. PT. Sidomulyo Selaras Tbk. PT. Samudera Indonesia Tbk.PT. Express Transindo Utama Tbk. PT. Pelayaran Tempur Emas Tbk. PT. Trada Maritime Tbk. PT. Weha Transportasi Indonesia Tbk. PT. Wintermar Offshore Marine Tbk. PT. Zebra Nusantara Tbk. sebesar 7,54. Nilai rata-rata dari variabel tingkat suku bunga adalah sebesar 6,8275 atau 682,75 persen. Standar deviasi dari variabel tingkat suku bunga adalah sebesar 0,75193 atau 75,193 persen. 
Hasil Uji Asumsi KlasikBerdasarkan hasil analisis Kolmogorov-Smirnov pada Tabel 3 diperoleh nilaiAsymp. Sig (2 tailed) sebesar 0,096 >level of significant sebesar 0,05 maka dapat disimpulkan bahwa model regresi berdistribusi normal.

Tabel 3.

Hasil Uji Normalitas

\begin{tabular}{llr}
\hline & & Unstandardized Residual \\
\hline $\mathrm{N}$ & & 96 \\
Normal Parameters & Mean &, 0000000 \\
& Std. & 44,37718789 \\
Most Extreme Differences & Deviation &, 126 \\
& Absolute &, 126 \\
& Positive &,- 080 \\
Kolmogorov-Smirnov Z & Negative & 1,233 \\
Asymp. Sig. (2-tailed) & &, 096 \\
\hline Sumber:www.bei.co.id,2017 & &
\end{tabular}

Tabel 4.

Hasil Uji Autokolerasi

\begin{tabular}{lrrrrr} 
Model & R & R Square & Adjusted R Square & Std. Error of the Estimate & Durbin-Watson \\
\hline 1 &, $521^{\mathrm{a}}$ &, 271 &, 248 & 45,09492 & 1,947 \\
\hline \multicolumn{2}{l}{ Sumber:www.bei.co.id,2017 } & & &
\end{tabular}

Penelitian ini menggunakan $\mathrm{N}$ (jumlah data) $=96$ dan $\mathrm{k}$ (jumlah variabel bebas $)=3$, maka diperoleh nilai $\mathrm{dL}=1,6039 \mathrm{dan} \mathrm{dU}=1,7326$. Berdasarkan Tabel 4 diperoleh nilai Durbin Watson (DW test) sebesar 1,947. Nilai tersebut berada diantara $\mathrm{dL}=1,6039$ dan $4-\mathrm{dU}=2,2674$ atau $1,6039<1,947<2,2674$ yang merupakan daerah bebas autokorelasi maka pengujian dengan Durbin Watson berada pada daerah tidak ada autokorelasi maka ini berarti pada model regresi tidak terjadi gejala autokorelasi.

Berdasarkan Tabel 5 menunjukan bahwa nilai Sig. dari variabel profitabilitas sebesar 0,270 , risiko bisnis sebesar 0,226 dan tingkat suku bunga 
sebesar 0,308. Berdasarkan hasil tersebut menunjukkan bahwa terdapat pengaruh antara variabel bebas terhadap absolute residual, dengan demikian model yang dibuat tidak mengandung gejala heteroskedastisitas.

Tabel 5.

Hasil Uji Heteroskedastisitas

\begin{tabular}{clrl} 
No & \multicolumn{1}{c}{ Variabel } & Sig & Keterangan \\
\hline 1 & Profitabilitas & 0,270 & Bebas heteroskedastisitas \\
2 & Risiko Bisnis & 0,226 & Bebas heteroskedastisitas \\
3 & Tingkat Suku Bunga & 0,308 & Bebas heteroskedastisitas \\
\hline
\end{tabular}

Sumber:www.bei.co.id,2017

Tabel 6.

Hasil Uji Multikolinearitas

\begin{tabular}{|c|c|c|c|}
\hline No & Variabel & $\begin{array}{c}\text { Nilai } \\
\text { Tolerance }\end{array}$ & Nilai VIF \\
\hline 1 & Profitabilitas & 964 & 1,037 \\
\hline 2 & Risiko Binis & ,994 & 1,006 \\
\hline 3 & Tingkat Suku Bunga & 961 & 1,040 \\
\hline
\end{tabular}

Berdasarkan Tabel 6 nilai tolerance untuk variabel profitabilitas sebesar 0,964; risiko bisnis 0,994 dan tingkat suku bunga 0,961 serta nilai VIF dari variabel profitabilitas, risiko bisnis dan tingkat suku bunga secara berturut-turut sebesar 1,037; 1,006 dan 1,040 sehingga dapat disimpulkan bahwa model regresi bebas dari multikolinearitas.

Berdasarkan Tabel 7 diperoleh rumus regresi linier berganda sebagai berikut:

$Y=186,931+0,856 X_{1}-0,510 X_{2}-16,382 X_{3}$

Keterangan:

$\begin{array}{ll}\mathrm{Y} & =\text { Struktur Modal } \\ \mathrm{X} 1 & =\text { Profitabilitas } \\ \mathrm{X} 2 & =\text { Risiko Bisnis }\end{array}$ 
X3 = Tingkat Suku Bunga

Tabel 7.

Hasil Analisis Regresi Linier Berganda

\begin{tabular}{|c|c|c|c|c|c|c|c|c|}
\hline \multirow{2}{*}{\multicolumn{2}{|c|}{ Model }} & \multicolumn{2}{|c|}{$\begin{array}{l}\text { Unstandardized } \\
\text { Coefficients }\end{array}$} & \multirow{2}{*}{$\begin{array}{c}\text { Standardized } \\
\text { Coefficients } \\
\text { Beta } \\
\end{array}$} & \multicolumn{2}{|c|}{$\begin{array}{c}\text { Corellation } \\
\text { Partial }\end{array}$} & \multirow[b]{2}{*}{$\mathrm{t}$} & \multirow[b]{2}{*}{ Sig. } \\
\hline & & B & $\begin{array}{l}\text { Std. } \\
\text { Error }\end{array}$ & & $\mathrm{r}$ & $\mathrm{r}^{2}$ & & \\
\hline \multirow[t]{4}{*}{1} & (Constant) & 186,931 & 42,910 & & & & 4,356 & ,000 \\
\hline & ROA & ,856 & , 170 & ,457 & , 420 &, 176 & 5,043 & ,000 \\
\hline & BRISK &,- 510 & 244 &,- 186 &,- 217 & ,047 & $-2,087$ & 040 \\
\hline & BIRATE & $-16,382$ & 6,292 &,- 236 &,- 165 & ,027 & $-2,604$ & ,011 \\
\hline \multicolumn{4}{|c|}{$\mathrm{R}^{2}$} & 271 & & & & \\
\hline \multicolumn{2}{|c|}{ Adjusted $R^{2}$} & & & 248 & & & & \\
\hline \multicolumn{2}{|c|}{ F Hitung } & & & 11,425 & & & & \\
\hline \multicolumn{2}{|c|}{ Sig. } & & & ,000 & & & & \\
\hline
\end{tabular}

Sumber:www.bei.co.id,2017

\section{Hasil Uji Kelayakan Model (Uji F)}

Uji statistik $\mathrm{F}$ digunakan untuk menguji apakah secara bersama-sama (simultan) variabel independen memiliki pengaruh terhadap variabel dependen. Berdasarkan Tabel 7 nilai $\mathrm{F}$ dalam penelitian ini adalah sebesar 11,425 dengan nilai signifikansi 0,000. Nilai signifikansi lebih kecil dari 0,05 atau 0,000<0,05 maka dapat disimpulkan bahwa profitabilitas, risiko bisnis dan tingkat suku bunga secara simultan mempengaruhi struktur modal.

\section{Hasil Uji Koefisien Determinasi (Uji $\left.\mathbf{R}^{2}\right)$}

Berdasarkan Tabel 7 nilai $R$ square pada penelitian ini adalah 0,271 yang berarti hanya 27,1 persen variasi dari variabel bebas (profitabilitas, risiko bisnis dan tingkat suku bunga) yang mampu menjelaskan variasi variabel terikat struktur 
modal, sedangkan struktur modal 72,9 persen dijelaskan oleh faktor di luar model. Nilai $R$-Square yang relatif rendah ini memiliki makna bahwa masih ada variabel penting diluar model penelitian yang dapat menjelaskan variasi dalam struktur modal.

\section{Pengaruh Profitabilitas terhadap Strukur Modal}

Hasil pengujian pada Tabel 7 menunjukkan bahwa nilai $r^{2}$ sebesar 0,176 atau 17,6 persen. Nilai ini memiliki arti bahwa sebesar 17,6 persen variasi struktur modal yang diproksikan dengan DAR dipengaruhi oleh variasi profitabilitas yang diproksikan dengan ROA. Setelah diuji secara statistik diperoleh nilai $t_{\text {hitung }}$ dari variabel profitabilitas yang diproksikan dengan ROA bernilai positif yaitu sebesar 5,043 dengan tingkat signifikansi 0,000 yaitu lebih kecil dari $\alpha=0,05$. Hal ini berarti $\mathrm{H}_{0}$ ditolak dan $\mathrm{H}_{1}$ diterima. Jika $\mathrm{H}_{1}$ diterima maka profitabilitas $\left(\mathrm{X}_{1}\right)$ berpengaruh positif signifikan terhadap struktur modal (Y).

Hasil dari penelitian ini menunjukkan bahwa profitabilitas berpengaruh positif terhadap struktur modal pada perusahaan transportasi di Bursa Efek Indonesia tahun 2012-2015. Hal ini sejalan dengan hipotesis pada penelitian ini yang menyatakan profitabilitas berpengaruh positif dan signifikan terhadap struktur modal, yang berarti meningkatnya profitabilitas diikuti denganmeningkatnya struktur modal. Meningkatnya tingkat pengembalian atas investasi, menyebabkan perusahaan memiliki cukup modal untuk memenuhi kebutuhan perusahaannya. Hasil penelitian ini menunjukan profitabilitas berpengaruh terhadap struktur modal, hal ini berarti bahwa besar kecilnya tingkat 
profitabilitas perusahaan mempengaruhi penggunaan hutang dalam struktur modal.

Hasil penelitian ini mendukung hasil penelitian yang dilakukan Ramlall (2009), Hovakimian et. al (2004) dan Seftianne (2011) yang menunjukan bahwa profitabilitas berpengaruh positif dan tidak signifikan terhadap struktur modal. Berbeda dengan hasil penelitian Bhawa (2015), Wimelda (2013) dan Damayanti (2013) yang menyatakan profitabilitas berpengarih negatif dan signifikan terhadap struktur modal.

\section{Pengaruh Risiko Bisnis terhadap Struktur Modal}

Hasil pengujian pada Tabel 7 menunjukkan bahwa $r^{2}$ sebesar 0,047 atau 4,7 persen. Nilai ini memiliki arti bahwa sebesar 4,7 persen variasi struktur modal yang diproksikan dengan DAR dipengaruhi oleh variasi risiko bisnis. Setelah diuji secara statistik diperoleh nilai $t_{\text {hitung }}$ dari variabel risiko bisnis bernilai negatif sebesar -2,087dengan tingkat signifikasi sebesar 0,040 yaitu lebih kecil dari $\alpha=$ 0,05. Hal ini berarti $\mathrm{H}_{0}$ ditolak dan $\mathrm{H}_{1}$ diterima. Jika $\mathrm{H}_{1}$ diterima maka risiko bisnis $\left(\mathrm{X}_{2}\right)$ berpengaruh negatif signifikan terhadap struktur modal (Y).

Hasil penelitian ini menyatakan bahwa risiko bisnis memiliki pengaruh negtaif dan signifikan terhadap struktur modal. Hal ini sejalan dengan hipotesis pada penelitian ini yang menyatakan risiko bisnis berpengaruh negatif dan signifikan terhadap struktur modal. Berati risiko bisnis berpengaruh nyata (signifikan) terhadap struktur modal perusahaan, hal ini dapat di artikanperusahaan dengan risiko bisnis yang tinggi cenderung menghindari pendanaan dengan menggunakan hutang dibandingkan dengan perusahaan yang 
risiko bisnisnya lebih rendah. Hasil pengujian ini mengartikan bahwa tinggi rendahnya risiko bisnis suatu perusahaan mempengaruhi struktur modal yang di ambil perusahaan. Hal ini sesuai dengan teori trade off, dimana semakin tinggi kemungkinan financialdistress akan semakin tinggi pula kemungkinanan financial distress costs yang harus di tangung perusahaan, ini akan menyebabkan tingkat penggunaan utang yang optimum semakin rendah, sehingga perusahaan seharusnya menggunakan lebih sedikit utang.

Penelitian ini mendukung penelitian yang dilakukan oleh Linda dan Aan (2013) dan Wimelda (2013) yang menunjukan bahwa risiko bisnis berpengaruh negatif dan signifikan terhadap struktur modal. Berbeda dengan hasil penelitian Sawitri (2015) dan Riyazahmed (2012) yang menyatakan risiko bisnis berpengarih positif dan tidak signifikan terhadap struktur modal.

\section{Pengaruh Tingkat Suku Bunga terhadap Struktur Modal}

Hasil pengujian pada Tabel 7 menunjukkan bahwa $r^{2}$ sebesar 0,027 atau 2,7 persen. Nilai ini memiliki arti bahwa sebesar 2,7 persen variasi struktur modal yang diproksikan dengan DAR dipengaruhi oleh variasi tingkat suku bunga (BI Rate). Setelah diuji secara statistik diperoleh nilai $t_{\text {hitung }}$ dari variabel tingkat suku bunga bernilai negatif sebesar -2,604 dengan tingkat signifikasi sebesar 0,011 yaitu lebih kecil dari $\alpha=0,05$. Hal ini berarti $\mathrm{H}_{0}$ ditolak dan $\mathrm{H}_{1}$ diterima.Jika $\mathrm{H}_{1}$ diterima maka tingkat suku bunga $\left(\mathrm{X}_{3}\right)$ berpengaruh negatif signifikan terhadap struktur modal (Y).

Hasil penelitian ini menyatakan bahwa tingkat suku bunga berpengaruh negative terhadap struktur modal. Hal ini sejalan dengan hipotesis pada penelitian 
ini yang menyatakan bahwa tingkat suku bunga berpengaruh negatif dan signifikan terhadap struktur modal. Hasil penelitian ini mengindikasikan tinggi rendahnya suku bunga perbankan di Indonesia mempengaruhi perusahaan dalam kebijakan pendanaan perusahaan.

Hubungan negatif yang diperoleh dalam penelitian ini mengandung arti tingkat suku bunga berbanding terbalik dengan struktur modal. Jika tingkat suku bunga naik maka struktur modal mengalami penurunan dan jika tingkat suku bunga mengalami penurunan maka struktur modal mengalami peningkatan. Bunga merupakan harga yang harus dibayar dari pinjaman, semakin tingginya tingkat suku bunga maka semakin besar harga yang harus dibayar.

Hasil penelitian ini mendukung hasil penelitian yang dilakukan Ilhamy (2013) yang menyatakan tingkat suku bunga berpengarih negatif dan signifikan terhadap struktur modal. Berbeda dengan hasil penelitian Mufidah (2012) yang menunjukan bahwa tingkat suku bunga berpengaruh negatif dan tidak signifikan terhadap struktur modal.

\section{SIMPULAN DAN SARAN}

Berdasarkan hasil analisis data dan pembahasan yang telah diuraikan, maka dapat diambil kesimpulan sebagi berikut: (1) Profitabilitas berpengaruh positif dan signifikan terhadap struktur modal pada perusahaan transportasi di BEI. Oleh karena itu, perusahaan dengan tingkat profitabilitas yang tinggi akan cenderung menggunakan pendanaan internal. (2) Risiko bisnis berpengaruh negatif dan signifikan terhadap struktur modal pada perusahaan transportasi di BEI. Hal ini berarti semakin tinggi risiko bisnis maka perusahaan akan mengurangi 
penggunaan hutang. (3) Tingkat suku bunga berpengaruh negatif dan signifikan terhadap struktur modal pada perusahaan transportasi di BEI. Artinya semakin tinggi tingkat suku bunga maka akan semakin rendah penggunaan hutang suatu perusahaan.

Berdasarkan pembahasan hasil penelitian dan simpulan tersebut, maka saran yang dapat diberikan adalah sebagai berikut: (1) Bagi perusahaan, dalam menetapkan kebijakan struktur modal hendaknya memperhatikan faktor risiko bisnis dari perusahaan itu sendiri karena faktor ini berpengaruh signifikan terhadap struktur modal. Perusahaan yang memiliki risiko bisnis cenderung akan menghindari menggunakan dana eksternal. (2) Bagi investor, sebelum menanamkan modalnya dalam suatu perusahaan investor hendaknya memperhatikan faktor risiko perusahaan. Perusahaan yang memiliki risiko bisnis yang tinggi juga akan berisiko besar bagi investor. Risiko yang tinggi akan berdampak pada kebangkrutan perusahaan yang akan berdampak pada dana yang ditanamkan investor. (3) Bagi peneliti selanjutnya, perlu menambahkan faktorfaktor lain yang mempengaruhi struktur modal sebagai variabel penelitian, hal ini dikarenakan masih banyak faktor-faktor lain yang dapat mempengaruhi struktur modal. Variabel bebas yang digunakan pada penelitian ini berpengaruh $27,1 \%$ terhadap struktur modal dan 72,9\% persen dipengaruhi oleh faktor lainnya. Selain itu, peneliti selanjutnya disarankan untuk menambah tahun pengamatan sehingga hasil yang diperoleh dapat dijadikan dasar pengambilan keputusan bagi pihakpihak yang membutuhkan.

\section{REFERENSI}


Alves, Paulo F. Pereira, Miguel A. Ferreira. (2011). Capital Structure and Law Around The World. Journal of Multinational Financial Management. Elsevier. 21, pp: 119-150.

Amiriyah. (2014). Pengaruh Kinerja Keuangan, Ukuran Perusahaan dan Risiko Bisnis Terhadap Struktur modal. Jurnal Ilmu dan Riset Akuntansi Sekolah Tinggi Ilmu Ekonomi Indonesia Surabaya. 3 (1).

Bhawa, Ida Bagus Made Dwija. (2015). Pengaruh Ukuran Perusahaan, Likuiditas, Profitabilitas dan Risiko Bisnis Terhadap Struktur Modal Perusahaan Farmasi. E-Jurnal Manajemen Unud. 4 (7), pp: 1949-1966

Brigham, Eugene F \& F Houston, Joel. (2011). Dasar-dasar Manajemen Keuangan (Essentials of Financial Management). Jakarta: Salemba Empat.

Damayanti. (2013). Pengaruh Struktur Aktiva, Ukuran Perusahaan, Peluang Pertumbuhan dan Profitabilitas terhadap Struktur Modal (Studi pada Perusahaan Farmasi yang Terdaftar di Bursa Efek Indonesia). Jurnal Perspektif Bisnis. 11 (1), pp: 17-32

Deesomsak, Rataporn,Krishna Paudyal, Gioia Pescetto. (2004). The Determinants of Capital Structure: Evidence from The Asian Pacific Region, Journal of Multinational Financial Management. 14, pp: 387-405.

Dewanti, Yossy Octa. (2011) Pengaruh profitabilitas, ukuran perusahaan, strukutr aktiva, likuiditas, dan risiko bisnis terhadap struktur modal perusahaan (Studi pada perusahaan sub sektor transportasi yang terdaftar di Bursa Efek Indonesia). Jurnal Ilmiah Mahasiswa FEB Universitas Brawijaya.

Gunawan, Ade. (2011). Pengaruh Profitabilitas dan Perputaran Aktiva terhadap Struktur Modal. Jurnal Manajemen dan Bisnis. 11 (1), pp: 12-24

Harris, M dan A. Raviv. (1991). The Theory of Capital Structure. Jounal of Finance. 46 (1), pp: 297-355

Hartono, Rudi Agung dan Apriani Dorkas Rambu Atahau. (2003). Analisis Interpedensi Insider Ownership, Tingkat Hutang dan DIviden Perusahaan Secara Simultan di Indonesia Periode 1990-1996 dan 2002-2003. Jurnal Ekonomi dan Bisnis. 13 (1), pp: 1-19

Hermuningsih, Sri. (2012). Pengaruh Profitabilitas, Size, terhadap Nilai Perusahaan dengan Struktur Modal Sebagai Variabel Intervening. Jurnal Siasat Bisnis Fakultas Ekonomi Universitas Sarjanawiyata Tamansiswa Yogyakarta. 16 (2), pp: 232-242.

Hovakimian, Armen, Gayene Hovakimian dan Hassan Tehranian. (2004). Determinants of Target Capital Structure: The Case of Dual Debt and Equity Issues. Journal of Financial Economics. 71, pp: 517-540 
Indrajaya, Glenn, Herlina dan Rini Setiadi. (2011). Pengaruh Struktur Aktiva, Ukuran Perusahaan, Tingkat Pertumbuhan, Profitabilitas dan Risiko Bisnis Terhadap Struktur Modal: Studi Empiris Pada Perusahaan Sektor Pertambangan yang Listing di Bursa Efek Indonesia Periode 2004-2007. Jurnal Imiah Mahasiswa Jurusan Akuntansi-UKM. 6 (2)

Insiroh, Lusia. (2014). Pengaruh Profitabilitas, Ukuran Perusahaan, Pertumbuhan Aset, dan Struktur Aset terhadap Struktur Modal. Jurnal Ilmu Manajemen Fakultas Ekonomi Universitas Negeri Surabaya. 2 (3), pp: 979-990.

Jensen, M.C. dan Meckling, W.H. (1976). Theory of the Firm: Managerial Behavior, Agency Cost and Ownership Structure. Journal of Financial Economics. 3, pp: 305-360

Kasmir. (2014). Analisis Laporan Keuangan ( $1^{\text {st }}$ ed). Jakarta: Rajawali Pers

Linda Imelda dan Aan Marlinah. 2013. Variabel-Variabel yang Mempengaruhi Struktur Modal pada Perusahaan Public Sektor Non Keuangan. 1, pp: 1-17

Liu, Yuanxin and Xiangbo Ning. (2009). Empirical Research of the Capital Structure Influencing Factors of Electric Power Listed Companies. International Journal of Marketing Studies. 1 (1), pp: 43-49

Mankiw, N Gregory. (2013). Pengantar Ekonomi Makro. Jakarta: Salemba Empat.

Mardiansyah, Tommy. (2013). Pengaruh Profitabilitas dan Operating Leverage terhadap Struktur Modal pada Perusahaan Makanan dan Minuman yang terdaftar di BEI Tahun 2008-2011. Jurnal Ilmiah Mahasiswa Fakultas Ekonomi Universitas Negeri Padang.

Mufidah, Ana. (2012). Stuktur Modal Perusahaan Properti dan Faktor-Faktor yang Mempengaruhinya. Jurnal Bisnis dan Manajemen. Fakultas Ekonomi Universitas Jember. 6 (1), pp: 45-54.

Ramlall, Indranarain. (2009). Determinants of capital structure among non-quoted Mauritian Firms Under Specificity of Leverage: Looking for a Modified pecking order theory. International Research Journal of Finance and Economics. ISSN 1450-2886, Issue 31

Riyazahmed, K. (2012). Determinant of Capital Structure: A Case of Automobile Manufacturing Companies Listed in NSE. International Journal of Marketing Financial Service \& Management Research. 1 (4), pp: 47-52

Sartono, Agus. (2010). Manajemen Keuangan Teori dan Aplikasi. Edisi Keempat. Yogyakarta: BPFE. 
Sawitri, Ni Putu Yuliana Ria. (2015). Pengaruh Risiko Bisnis, Ukuran Perusahaan dan Pertumbuhan Penjualan Terhadap Struktur Modal. E-Jurnal Manajemen Unud. 4 (5), pp: 1238-1251

Seftianne dan Handayani, ratih. (2011). Faktor-Faktor yang mempengaruhi Struktur Modal pada Perusahaan Publik Sektor Manufaktur. Jurnal Bisnis dan Akutansi. 13 (1), pp: 39-56

Setiawati, Rike. (2011). Faktor-faktor yang Mempengaruhi Struktur Modal (Survei pada Perusahaan Sanitaer di Kota Jambi). Jurnal Manajemen Keuangan dan Portofolio. 1 (1).

Sudana, I Made. (2011). Manajemen Keuangan Perusahaan Teori dan Praktik. Jakarta: Erlangga

Tandelilin, Eduardus. (2010). Portofolio dan Investasi. Yogyakarta: Kanisius

Wahyuni, Wenny Setyo. (2013). Pengaruh Karakteristik Perusahaan terhadap Struktur Modal Perusahaan Manufaktur pada Bursa Efek Indonesia. Jurnal Ilmu dan Riset Manajemen. 2 (9), pp: 1-15

Wiagustini, Ni Luh Putu. (2014). Dasar-dasar Manajemen Keuangan. Cetakan Pertama. Denpasar: Udayana University Press.

Wimelda, Linda dan Marlinah, Aan. (2013). Variabel-Variabel yang Mempengaruhi Struktur Modal pada Perusahaan Sektor Non Keuangan. Media Bisnis. pp: 200-2013

Zhang, Ye. (2010). The Product Category Effects on Capital Structure: Evidence from the SMEs of British Manufacturing Industry. International Journal of Bussiness and Management. 5 (8), pp: 86-112 